\title{
Gene signatures of cyclin-dependent kinases: a comparative study in naïve early and advanced stages of lung metastasis breast cancer among pre- and post-menopausal women
}

\author{
Muhammad Fazal Hussain Qureshi ${ }^{1}$, Muzna Shah ${ }^{1}$, Mahira Lakhani ${ }^{1}$, Zain Jawed \\ Abubaker ${ }^{1}$, Danish Mohammad ${ }^{1}$, Hira Farhan ${ }^{1}$, Iman Zia ${ }^{1}$, Rida Tafveez ${ }^{1}$, Samahir \\ Tariq Khan ${ }^{1}$, Rubina Ghani ${ }^{2}$, Shamim Mushtaq ${ }^{3}$, Ghulam Haider ${ }^{4}$ \\ ${ }^{1}$ Medical Students, Ziauddin University, Clifton, Karachi, Pakistan \\ 2 Department of Biochemistry, Sohail University, Karachi, Pakistan \\ ${ }^{3}$ Department of Biochemistry, Ziauddin University, Clifton, Karachi, Pakistan \\ ${ }^{4}$ Oncology Department, Jinnah Postgraduate Medical Center, Karachi, Pakistan \\ Correspondence to: Shamim Mushtaq, email: shamim.mushtaq@zu.edu.pk \\ Keywords: cyclin-dependent kinases; breast cancer; menopause; human epidermal growth factor receptor 2 \\ Received: July 17, $2020 \quad$ Accepted: December 03, $2020 \quad$ Published: February 10, 2021
}

Copyright: @ 2021 Qureshi et al. This is an open access article distributed under the terms of the Creative Commons Attribution License (CC BY 3.0), which permits unrestricted use, distribution, and reproduction in any medium, provided the original author and source are credited.

\section{ABSTRACT}

The Human epidermal growth factor receptor 2 positive (HER2+) breast cancer (BC) is a more aggressive tumor with 5 years median survival rates after metastasis. Despite successful treatment, unfortunately, the majority of affected patients die. Defects in cell cycle and transcription regulation phases which are governed by cyclindependent kinases (CDKs) are the hallmark of many cancers that underpinning the progression of the disease. Therefore, the current study looked at the alteration of six CDKs mRNA expression levels in pre- and postmenopausal lung metastasis BC groups; the majority were HER2+. Two hundred pre-and postmenopausal lung metastasis breast cancer and healthy control blood samples were taken for RNA isolation. Quantitative PCR was done for CDKs mRNA expressions. We observed overexpression of CDK11, CDK12, CDK17, CDK18, and CDK19 in both pre- and postmenopausal groups. However, CDK20 showed progressive downregulation from early to advanced stages in both groups of patients. Collectively, this data revealed that CDKs overexpression levels may predict BC disease progression and provide further rationale for novel anticancer strategies for HER2+ BC cancers.

\section{INTRODUCTION}

Breast cancer (BC) in women is a severe health burden worldwide and responsible for about 375,000 deaths in the year 2000. It is a major cause of cancer in both high- and low-income countries [1]. Many studies have shown poor prognosis at a young age. Cancer in this age group is more aggressive [2-4]. In Asia and other lesser developed countries, there is a lack of adequate services and treatment for $\mathrm{BC}$, hence a higher mortality rate is observed when compared to a developed setup [57].

In Pakistan, Karachi is supposed to have the highest incidence of $\mathrm{BC}$ among the Asian population
[8]. Nonetheless, the age-standardized incidence rate of $\mathrm{BC}$ is highest in Pakistan among Asian countries [9]. The $\mathrm{BC}$ lung metastatic relapse has become a serious clinical problem due to a lack of treatment, shorter survival time, and a high mortality rate [10-13]. Unfortunately, due to late diagnosis, the mortality rate in $\mathrm{BC}$ is high in Pakistan. Currently, there is no data available regarding the most occurring metastatic site in BC Pakistani patients. Human epidermal growth factor receptor 2 (HER2) known as an oncogene, confers a more aggressive tumor and is associated with an increased rate of recurrence, mortality, and metastatic disease despite the remarkable progress in treatment [14-15]. Unfortunately, at advanced stages, patients might fail to respond to targeted therapies. 
Patients may also have an initial response followed by development of resistance. Therefore, a strategy that investigates the target transcription elements might be more effective in HER2 positive BC patients. Moreover, there is no progress in $\mathrm{BC}$ in recent times. To generate accurate data, there is an urgent requirement to discover diagnostic, prognostic non-invasive blood biomarkers for predicting clinical outcomes at an early stage and selecting patients who could benefit after treatment. It has been postulated that various alternative pathways like cell-cycle dysregulation, apoptosis, growth factor and androgen receptor pathways are involved in breast cancer [16-21].

Cyclin-dependent kinases (CDKs) regulate the cell cycle progression and transcriptional regulation which is frequently dysregulated in all human malignancies. They are an attractive target for BC therapeutic strategy [2223]. Therefore, they have been the interest of the current study. More recently, a CDK4/6 inhibitor, palbociclib was approved by the FDA for treating metastatic breast cancer [24-25]. Overexpression, dysregulation, and mutation of these CDKs contribute to the proliferation of cancer cells and inhibition can lead to both cell cycle arrest and apoptosis [26].

CDK11 (formerly named PITSLRE) is an essential CDK for cell survival, and its increased expression in various cancers is associated with poor prognosis [27-29]. While CDK12 is known to protect the normal cell from DNA damage and is involved in the regulation of RNA polymerase II (RNApol II) [30-31]. In contrast to other cell cycle CDKs family regulators, CDK11, CDK12, CDK19, and CDK20 are the transcriptional regulators that control fundamental cellular processes. Furthermore, previously CDK12 functional mutation was reported which hampered its ability to promote tumor suppressor gene in ovarian carcinoma [32]. Recent data shows the highest expression of CDK19 in metastatic prostate cancer. However, a past study revealed novel links between CDK19 and cell proliferation through repression of p53 response [33-34]. CDK20 is a newly identified human CDK family protein that is known to control cell cycle progression in various cancers [35-36].

There is little progress on the CDK17 and CDK18 in recent times. Their role in the cell cycle and expression in $\mathrm{BC}$ remains unclear. Moreover, the role of CDK11, CDK12, CDK19, and CDK20 in metastatic BC and molecular mechanisms associated with CDKs mRNA expression are poorly understood. The advanced stage of $\mathrm{BC}$ is a crucial clinical problem and poses a challenge to the clinician. Thus, the present study aims to investigate the six CDKs 11, 12, 17, 18, 19 and 20 mRNA expression at an early stage (II) and advanced stage (III and IV) with lung metastasis patients; early detection for new approaches to treat pre- and postmenopausal naïve $\mathrm{BC}$ lung metastatic.

\section{RESULTS}

Patients were divided into two groups based on their menopausal status as pre-menopausal and postmenopausal associated with lung metastasis. We quantified six CDKs gene transcripts in both groups at early (II) and advanced stages (III \& IV). The mean age for pre-menopausal participants was 30 with a standard deviation of 3.8 years, while the mean age of postmenopausal participants was 45 , with a standard deviation of 2.8 years.

$90 \%$ of the participants reported no prior family history of breast cancer. Out of 150 pre-menopausal BC patients, 140 were HER-2+, and 10 were negative while among 100 postmenopausal 90 were HER-2+, and 05 were negative. Detailed clinicopathological characteristics of the studied cases are presented in Table 1.

The total RNA was isolated from each pre- and postmenopausal $\mathrm{BC}$ blood samples and primers used for this study are summarised in table 2 . To investigate the role of CDKs in different stages of $\mathrm{BC}$, the mRNA expression of CDKs $[11,12,17,18,19,20]$ was measured using RT-qPCR. The cycle threshold $(\mathrm{Ct})$ values (Figure 1) were used to determine the amount of mRNA and $\mathbf{\Delta} \mathrm{Ct}$ values were then determined by calculating the median absolute deviation for all the samples within the same experimental group. Samples that did not correlate with the results were declared as outliers and excluded from the analysis. Relative change for expression of marker and housekeeping gene (GAPDH) was determined by the Levene equation ( $\boldsymbol{\Delta} \boldsymbol{\Delta} \mathrm{Ct}$ values). ANOVA was used to determine the statistical significance of the observed fold change, and a p-value of less than 0.05 was considered as significant. The relative fold change in the CDKs mRNA expression level of pre- and postmenopausal BC was shown as the $2^{\wedge}-\boldsymbol{\Delta} \boldsymbol{\Delta} \mathrm{Ct}$ values. The average gene expression values $(\boldsymbol{\Delta} \mathrm{Ct})$ were compared between the healthy control group and the $\mathrm{BC}$ patients (Figure 2). ANOVA and Post-hoc Tukey test was applied to determine intergroup group means and variations.

In the pre-menopausal $\mathrm{BC}$ group (Tables $3 \& 4$ ), the relative gene expression of CDK11 (Figure 2A) was found to be high in advanced stages (IV) only, with statistical significance $(p=0.0001)$. However, in the postmenopausal group, it showed progressively increased expression from stage III to stage IV with statistical significance $(p=$ $0.001)$.

We found CDK12 up-regulated at both early and advanced stages in the pre-menopausal group. Earlystage did not reach statistical significance $(p=0.06)$. Interestingly, in the postmenopausal group, upregulation was observed in CDK12 only in advanced stages, and stage IV did not show statistical significance $(p=0.06)$.

The mRNA expression level of CDK17 in the pre-menopausal group was overexpressed with a 
Table 1: Study set and clinicopathological features

\begin{tabular}{|l|l|l|}
\hline Variables & Pre-menopausal BC & Postmenopausal BC \\
\hline No of BC patients & 150 & 100 \\
\hline Mean age at sample draw (years; range) & $30 \pm 3.8$ & $45 \pm 2.8$ \\
\hline $\begin{array}{l}\text { Tumour grade (number of cases) } \\
1\end{array}$ & 55 & 35 \\
2 & 35 & 35 \\
3 & 60 & 30 \\
\hline Node status (number of cases) & 70 & \\
N0 & 25 & 80 \\
N1 & & 20 \\
\hline Stage (number of cases) & 50 & 35 \\
II & 50 & 35 \\
III & 50 & 30 \\
\hline IV & 140 & 90 \\
\hline HER-2 status & 10 & 05 \\
Nositive & & 60 \\
\hline Metastasis (number of cases) & 80 & 30 \\
M0 & 50 & \\
M1 & & \\
\hline
\end{tabular}

Table 2: Primers sequences used in qPCR

\begin{tabular}{|l|l|}
\hline Target gene & Primer Sequences \\
\hline CDK11 & $\begin{array}{l}\text { F'AGAACATATTCGACTCTCCAGCACT } \\
\text { R'GAGTATTCCTTAGCACCAAGCAGTA }\end{array}$ \\
\hline CDK12 & $\begin{array}{l}\text { F' TGG ACT TGC TCG GCT CTA TAA CTC } \\
\text { R' CCC AAG AAT ACA TCC ACA GCT CCA }\end{array}$ \\
\hline CDK17 & $\begin{array}{l}\text { F' CATAGACGGATCTCAATGGAGGA } \\
\text { F'TGGTTGGTCAAATGGTGGACT }\end{array}$ \\
\hline CDK18 & $\begin{array}{l}\text { F' GAGTTCCGCACCTACAGCTTCC } \\
\text { R'GCCTCGGTAGCCTGGGTCTT }\end{array}$ \\
\hline CDK19 & $\begin{array}{l}\text { F' CGGAACCTATTTTTCACTGTCG } \\
\text { R'TGTGGGATATTCTGGCATCTT }\end{array}$ \\
\hline & $\begin{array}{l}\text { F' TCCAAGGCTCTCCTCCATCA } \\
\text { R'TCTGGGTTCAACAGCGACTC }\end{array}$ \\
\hline
\end{tabular}

gradual increase in expression in advanced stages compared to the early stage. We also found a statistically significant increase $(p=0.001)$ in mRNA expression of postmenopausal patients at an advanced stage (III) compared to stage IV; the early stage did not reach statistical significance $(p=0.098)$.

The statistically significant approach was seen in CDK18 mRNA expression, which was up-regulated in all stages among pre- and postmenopausal groups.

CDK19 was overexpressed only in stage IV of the pre-menopausal group with $p=0.002$. The postmenopausal group showed a 5.52 -fold increase of CDK19 expression at an advanced stage (IV) only, with statistical significance $p=0.04$. Whereas CDK20 showed downregulation progressively from early to advanced stages in pre- and postmenopausal.

\section{DISCUSSION}

Our current study has revealed six CDKs gene signatures in $\mathrm{BC}$ among pre and postmenopausal women at early (II) and advanced stages (III \& IV) with lung metastasis. Among $250 \mathrm{BC}$ patients, we found 150 pre-menopausal (mean age $30 \pm 3.8$ ) and rest were postmenopausal (mean age $45 \pm 2.8$ ). According to a 
survey conducted in Karachi, the average incidence of BC presentation was $27.4 \%$ between the age of 25-37 years, which was highest compared to other cancer presentation age groups [8]. As to why the rates of pre-menopausal breast cancer in Pakistan are so high is not yet known. It can occur due to delay in seeking medical attention, a conservative society, and religious beliefs that do not permit talks about BC in our setup.

The principal regulators of various cellular processes, CDKs personify the cell molecular machinery, associated with both cell cycle and transcription phases which represent typical oncogenes and tumor suppressors. However, deranges reflect an unscheduled division of the cell, which could lead to uncontrolled proliferation and tumorigenesis. To the best of our knowledge, this is the first study showing six CDKs mRNA expressions in preand postmenopausal $\mathrm{BC}$ patients associated with lung metastasis.

It is recognized that CDK18/ PCTK3 is required for $\mathrm{S}$ phase transit, and its inhibition leads to DNA
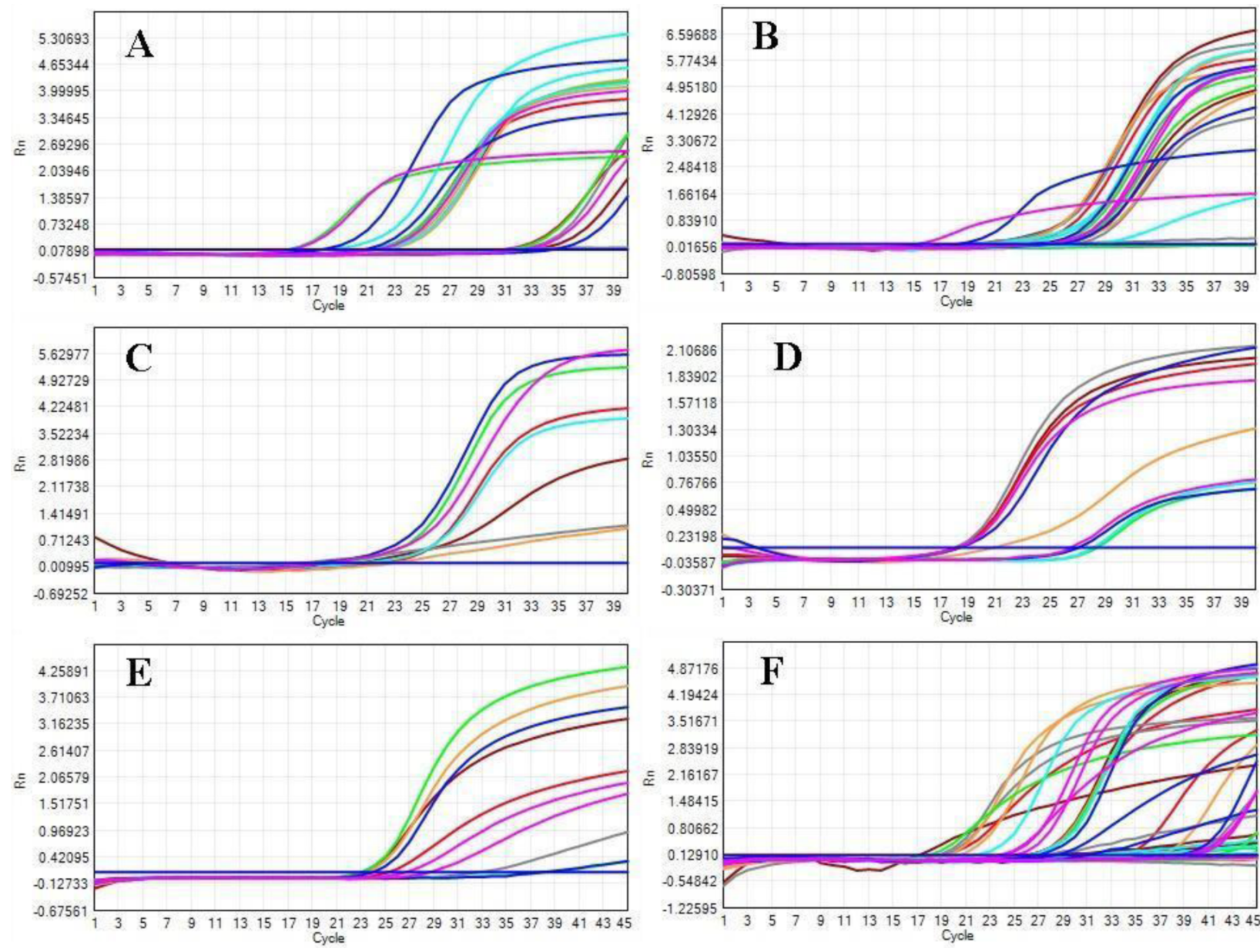

damage, defects in replication, and chromosomal abnormalities [37]. The most significant finding of this study is the overexpression of CDK18 found at both early and advanced stages in two groups. However, in the postmenopausal group, it exhibited a slight up-regulation in advanced stages. It is difficult to disseminate if these changes are actively involved during tumorigenesis or it occurs due to genetic alteration. A study showed that antiHER2 therapies improved the outcome of metastatic BC [38], while metastatic HER2+ is still an incurable disease as patients showed resistance to current treatment that could lead to tumor progression and death [39]. In support of our findings, a recent study also observed higher levels of CDK18 mRNA and protein expression in BC compared to the normal breast [40].

CDK 17, also known as PCTAIRE-2/PCTK2, was not studied much in cancer. However, recently it was considered a potential inhibitor of autophagy implicated in several pathological conditions such as cancer, neurodegenerative diseases, and infections [41]. Moreover,

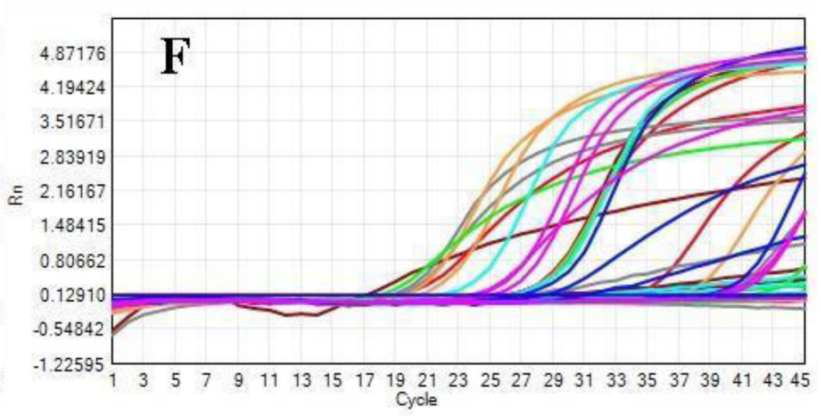

Figure 1: An amplification curves of CDKs showing respective Ct values for two distinctive stages early (II) and advanced stages (II \& IV) of pre-and postmenopausal BC patients. A. CDK 11 B. CDK 12, C. CDK17, D. CDK18, E. CDK F. CDK 20. 
Table 3: $\Delta \mathrm{Ct}$ mean, $\Delta \Delta \mathrm{Ct}, 2-\Delta \Delta \mathrm{Ct}$ and $\mathrm{p}$ values for CDKs differentially expressed gene in early and advanced stage BC Pre-menopausal groups

\begin{tabular}{|c|c|c|c|c|c|c|c|c|c|c|c|c|c|c|c|}
\hline \multirow{3}{*}{ CDKs } & \multicolumn{5}{|c|}{ Early-stage } & \multicolumn{10}{|c|}{ Advanced stages } \\
\hline & \multicolumn{5}{|l|}{ II } & \multicolumn{5}{|l|}{ III } & \multicolumn{5}{|l|}{ IV } \\
\hline & $\begin{array}{l}\Delta \mathrm{Ct} \\
\text { mean } \\
\mathrm{BC}\end{array}$ & $\begin{array}{l}\Delta \mathrm{Ct} \\
\text { mean } \\
\text { control }\end{array}$ & $\underset{\mathbf{C t}}{\Delta \boldsymbol{\Delta}}$ & $\begin{array}{l}2^{\wedge}- \\
\Delta \Delta C t\end{array}$ & $p$-Value & $\begin{array}{c}\Delta \mathrm{Ct} \\
\text { mean } \\
\mathbf{B C}\end{array}$ & $\begin{array}{l}\Delta \mathrm{Ct} \\
\text { mean } \\
\text { control }\end{array}$ & $\underset{\mathbf{C t}}{\Delta \boldsymbol{\Delta}}$ & $\begin{array}{l}2^{\wedge}- \\
\Delta \Delta C t\end{array}$ & $p$-Value & $\begin{array}{l}\underset{\text { mean }}{\Delta \mathrm{Ct}} \\
\mathrm{BC}\end{array}$ & $\begin{array}{l}\Delta \mathrm{Ct} \\
\text { mean } \\
\text { control }\end{array}$ & $\underset{\mathbf{C t}}{\Delta \boldsymbol{\Delta}}$ & $\begin{array}{l}2^{\wedge}- \\
\Delta \Delta C t\end{array}$ & $p$-Value \\
\hline 11 & 2.19 & 1.56 & 0.63 & 0.646 & 0.04 & 2.59 & 1.56 & 1.03 & 0.489 & 0.001 & 14.29 & 1.56 & 12.73 & $1.47 \times 10^{-4}$ & 0.0001 \\
\hline 12 & 17.40 & 2.21 & 15.19 & $2.67 \times 10^{-5}$ & 0.067 & 15.21 & 3.41 & 11.80 & $2.80 \times 10^{-4}$ & 0.001 & 18.25 & 2.60 & 15.65 & $1.94 \times 10^{-5}$ & 0.0001 \\
\hline 17 & 13.81 & 4.32 & 9.49 & $1.3 \times 10^{-3}$ & 0.001 & 14.81 & 4.32 & 10.49 & $6.95 \times 10^{-4}$ & 0.0001 & 16.63 & 3.75 & 12.88 & $1.32 \times 10^{-4}$ & 0.001 \\
\hline 18 & 19.21 & 1.11 & 18.1 & $3.5 \times 10^{-6}$ & 0.04 & 18.90 & 1.41 & 17.4 & $5.7 \times 10^{-6}$ & 0.04 & 16.63 & 3.75 & 12.88 & $1.32 \times 10^{-4}$ & 0.0001 \\
\hline 19 & 6.28 & 1.48 & 4.8 & 0.035 & 0.02 & 4.45 & 0.95 & 3.5 & 0.088 & 0.001 & 14.15 & 3.65 & 10.5 & $6.90 \times 10^{-4}$ & 0.002 \\
\hline 20 & 1.41 & 0.47 & 0.94 & 0.521 & 0.05 & 1.50 & 0.89 & 0.61 & 0.655 & 0.05 & 1.20 & 0.23 & 0.97 & 0.510 & 0.04 \\
\hline
\end{tabular}

${ }^{*} p<0.05=$ statistically significant; $\mathrm{Ct}=$ Threshold cycle.

Table 4: $\Delta \mathrm{Ct}$ mean, $\Delta \Delta \mathrm{Ct}, 2-\Delta \Delta \mathrm{Ct}$ and $\mathrm{p}$ values for CDKs differentially expressed gene in early and advanced stage BC Post-menopausal groups

\begin{tabular}{|c|c|c|c|c|c|c|c|c|c|c|c|c|c|c|c|}
\hline \multirow{3}{*}{ CDKs } & \multicolumn{5}{|c|}{ Early-stage } & \multicolumn{10}{|c|}{ Advanced stages } \\
\hline & \multicolumn{5}{|l|}{ II } & \multicolumn{5}{|l|}{ III } & \multicolumn{5}{|l|}{ IV } \\
\hline & $\begin{array}{l}\Delta \mathrm{Ct} \\
\text { mean } \\
\mathrm{BC}\end{array}$ & $\begin{array}{l}\Delta \mathrm{Ct} \\
\text { mean } \\
\text { control }\end{array}$ & $\underset{\mathrm{Ct}}{\Delta} \boldsymbol{\Delta}$ & $\stackrel{2^{\wedge}-}{\Delta \Delta C t}$ & $p$-Value & $\begin{array}{l}\underset{\text { mean }}{\Delta C t} \\
\mathbf{B C}\end{array}$ & $\begin{array}{l}\Delta \mathrm{Ct} \\
\text { mean } \\
\text { control }\end{array}$ & $\underset{\mathrm{Ct}}{\Delta \boldsymbol{\Delta}}$ & $\begin{array}{l}2^{\wedge}- \\
\Delta \Delta C t\end{array}$ & $p$-Value & $\begin{array}{l}\Delta C \mathrm{Ct} \\
\text { mean } \\
\mathrm{BC}\end{array}$ & $\begin{array}{l}\Delta \mathrm{Ct} \\
\text { mean } \\
\text { control }\end{array}$ & $\underset{\mathbf{C t}}{\Delta \boldsymbol{\Delta}}$ & $\begin{array}{l}2^{\wedge}- \\
\Delta \Delta C t\end{array}$ & $p$-Value \\
\hline 11 & 1.65 & 1.56 & 0.09 & 0.939 & 0.001 & 6.66 & 1.59 & 5.06 & 0.029 & 0.001 & 12.12 & 1.56 & 10.52 & $6.8 \times 10^{-4}$ & 0.001 \\
\hline 12 & 4.28 & 3.33 & 0.95 & 0.517 & 0.047 & 14.57 & 2.21 & 12.41 & $1.83 \times 10^{-4}$ & 0.01 & 11.87 & 2.21 & 9.66 & $1.23 \times 10^{-3}$ & 0.06 \\
\hline 17 & 12.69 & 4.32 & 8.37 & $3.0 \times 10^{-3}$ & 0.098 & 16.25 & 4.32 & 11.93 & $2.56 \times 10^{-4}$ & 0.04 & 15.19 & 4.32 & 10.87 & $5.34 \times 10^{-4}$ & 0.001 \\
\hline 18 & 18.22 & 0.32 & 17.91 & $4.0 \times 10^{-6}$ & 0.03 & 19.26 & 0.96 & 18.31 & $3.0 \times 10^{-6}$ & 0.014 & 19.62 & 0.71 & 18.91 & $2.04 \times 10^{-6}$ & 0.001 \\
\hline 19 & 14.34 & 2.81 & 11.50 & $3.45 \times 10^{-4}$ & 0.001 & 15.12 & 5.32 & 9.8 & $1.12 \times 10^{-3}$ & 0.001 & 16.23 & 8.73 & 7.51 & 5.52 & 0.04 \\
\hline 20 & 2.06 & 1.41 & 0.65 & 0.637 & 0.02 & 4.52 & 1.01 & 3.50 & 0.088 & 0.06 & 1.41 & 0.70 & 0.71 & 0.611 & 0.04 \\
\hline
\end{tabular}

${ }^{*} p<0.05=$ statistically significant; $\mathrm{Ct}=$ Threshold cycle.

its increased expression was also found in Alzheimer's disease, promoting neurodegeneration [42]. We also observed CDK17 overexpression in advanced stages of pre- and postmenopausal BC group. Therefore, in support of previously reported studies, we can predict that CDK17 upregulation may be required to stimulate autophagy, an event frequently found in breast tumorigenesis [41].

The CDK19, homolog CDK8, contributes to the first stage of gene expression by forming a mediator complex that links to transcription factor Pol II to regulate different transcription programs [43-44]. However, a study identified novel links between CDK19, cell proliferation, and $\mathrm{p} 53$ response [34]. In the current study, CDK19 upregulation is noted in the pre-menopausal group compared to the postmenopausal BC group. Furthermore, a previous study has also focused on high expression of both CDK8 and CDK19 in prostate cancer metastases [45]. 
CDK20 also known as CCRK, which has sequence homology to $\mathrm{CDK} 7$, represents a novel cell cyclerelated kinase (CAK) activity, and controls cell cycle

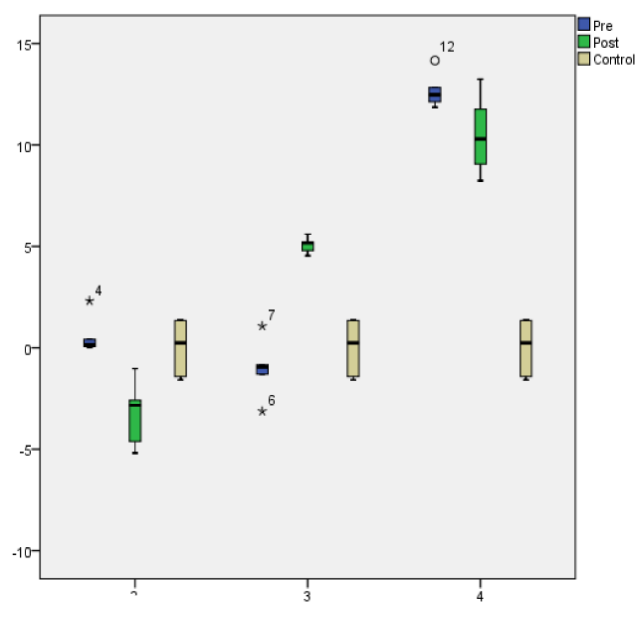

A
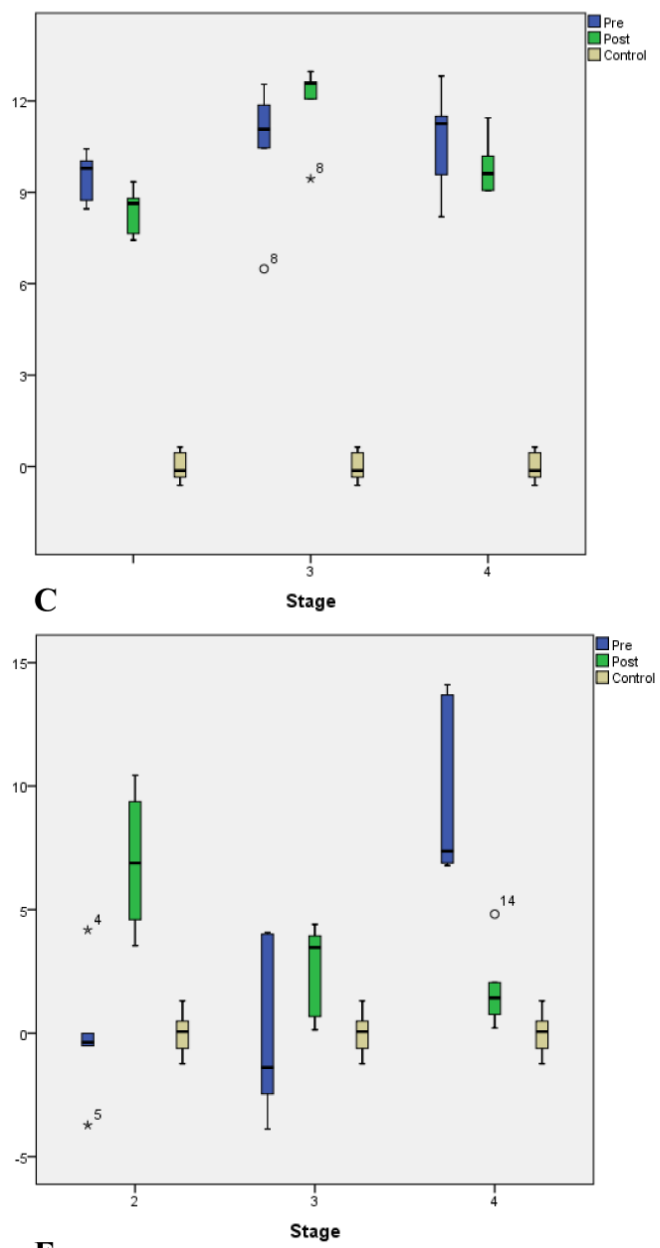

E progression [46] in various cancers including lung [47], colorectal, liver and ovarian cancer [36, 48-50]. More recently, Bowen Sun et al. revealed that CDK 7 inhibition
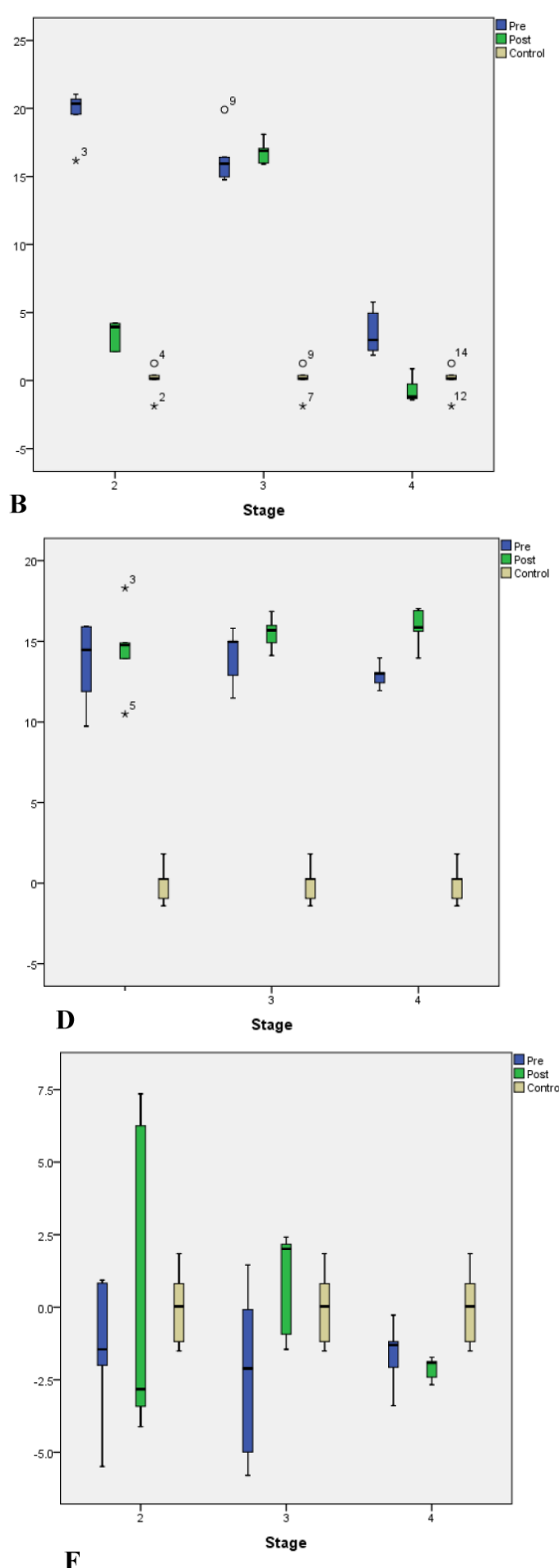

F

Figure 2: Box plots showing CDKs relative expressions $\Delta \Delta \mathrm{Ct}$ values of control and all pre- and postmenopausal $\mathrm{BC}$ groups at early and advanced stages validated by qPCR. All data were normalized against levels of GAPDH mRNA expression within the $\mathrm{BC}$ and control samples. Error bars indicate $\pm \mathrm{SD}, \mathrm{P}<0.005$ after three individual experiments. A. The CDK 11, B. CDK 12 , C. CDK17, D. CDK 18, E. CDK 19, and F. CDK 20. 
blocks the activation of genes associated with HER2 inhibitor-resistant (HER2iR) in BC xenograft models in vivo [51]. Moreover, further study revealed that CDK20 results in EZH2 (zeste homolog 2) upregulation and may be associated with poor survival in liver cancer [49]. Precisely how CDK20 functions in breast cancer remain largely unknown. Consistent with these studies, we tried to explore the function of CDK20 in BC early and advanced stages. It was found that it was highly expressed only in advanced stage (IV) of the pre-menopausal group compared to postmenopausal BC group. The Kelchlike ECH-associated protein 1 (KEAP1)-nuclear factor erythroid-2-related factor 2 (NRF2) cytoprotective pathway regulates cell growth, cell metabolism, cell proliferation, elimination of reactive oxygen species (ROS), gene transcription, essential events in cellular redox homeostasis and tumorigenesis. CDK20 modulates the KEAP1-NRF2 cytoprotective pathway and regulates tumor progression, implying that it is a potent therapeutic target for lung cancer [47]. This would suggest that overexpression of CDK20 at an advanced stage of lung metastasis in pre-menopausal BC may regulate KEAP1NRF2 cytoprotective pathway. On this account, it will be interesting to investigate the expression in different treated $\mathrm{BC}$ patients in the future.

We also observed overexpression of CDK11 at an advanced stage (IV) in both pre-and postmenopausal $\mathrm{BC}$ groups compared to the early stage. The CDK11 is involved in transcription and RNA processing events by interacting with its regulatory partner cyclin L [5254], but also is implicated in other cellular processes, including autophagy [53]. Similar to our results, Zhou $\mathrm{Y}$ and his group found elevated CDK11p110 expression in breast cancer tissues significantly correlating with poor differentiation and was also associated with clinicopathological characteristics of breast cancer patients [54]. Our results suggest that elevated CDK11 expression might be crucial for the proliferation and growth of human breast cancer metastasis.

The CDK12 (CRKRS, CRKR, or CRK7) is ubiquitously expressed, in different human tissues [56]; higher expression was seen in male and female endocrine tissue, reproductive tissue, spleen and bone marrow mainly localized in the nucleus [57]. Inactivation of the CDK12 gene has been associated with a unique genomic instability pattern that could lead to tumorigenesis [59]. Furthermore, CDK12 also lethally interacts with protooncogenes such as MYC and EWS/ FLI (Ewing sarcoma (ES) oncoprotein) and these interactions also provide an opportunity for a therapeutic target [59-60]. The current study showed a high expression of CDK12 at early and advanced stages of pre- and postmenopausal group, but only slightly increased in the pre-menopausal group. The question remains unclear whether these alterations are due to the mutation or interaction with some oncogenes.

Taken together, clinical studies on CDKs inhibitors, are needed to investigate the role of these CDKs in advanced stages HER2+ BC patients. Furthermore, clinical trials will also clarify whether these CDKs will become targets for the treatment of metastatic HER2+BC patients.

\section{MATERIALS AND METHODS}

\section{Ethical statement}

Breast cancer (BC) blood samples were obtained from Ziauddin Hospital and Jinnah Postgraduate Medical Centre (JPMC), Karachi. All the patients enrolled in the current study signed the consent form. The study was approved by the Ethics Review Committee (ERC) of Ziauddin University (Reference No: 0220518S MBC).

\section{Patient recruitments and sample collection}

Peripheral blood $(5 \mathrm{ml})$ was collected from premenopausal $(n=100)$ ranging from 30 to 44 years of age, postmenopausal $(n=100)$ ranging from 45 to 60 years of age naïve (untreated) BC patients. The healthy controls $(n=50)$ with a similar distribution of age were recruited from the same hospital. The whole blood in EDTA tubes was stored at $-20^{\circ} \mathrm{C}$ in the freezer.

Postmenopausal status was confirmed, those who had no menstrual flow for 12 months, and rest considered as pre-menopausal. Patients characteristics are shown in Table 1. Briefly, naïve BC patients were selected based on the mammographic appearance of the tumor, basal phenotype, and the histologic tumor distribution together with the conventional tumor attributes (tumor size, axillary node status, and histologic malignancy grade). Using the TNM system, staging for each case will be determined, tumor size $(\mathrm{T})$, spread to the lymph nodes $(\mathrm{N})$, and whether the tumor metastasized (M).

Among them, patients with stage II were grouped as early-stage pre- and post-menopause BC. The advanced stage pre and post-menopause BC group comprised of patients with stages III and IV (lung metastasis); metastatic changes start during stage III leading it to stage IV.

Women who had undergone hysterectomy, had any ovarian problems, had a personal history of any other cancer, or had undetermined menopausal state were excluded from the study. Immunohistochemical staining was done on paraffin sections and stained with antibodies against ER; PR and HER2. Immunohistochemical results were scored, and tumors were considered positive 
for hormone receptors if at least $1 \%$ of the tumor cells showed nuclear staining. According to the guidelines for the assessment of HER2 status, staining for HER2 will be scored: 0 , no staining; $1+$, (weak staining in $<10 \%$ of tumor cells), $2+$, moderately strong membrane staining in $>10 \%$ of the tumor cells; $3+$, strong membrane staining in $>10 \%$ of the tumor cells.

\section{RNA Extraction and RT-qPCR analysis}

Total RNA was extracted from whole blood of pre and postmenopausal naïve BC patients at early (II) and advanced stages (III \& IV) using an extraction kit (VIOGENE, USA) according to the manufacturer's protocol and immediately stored at $-80 \mathrm{C}$. The isolated 5ng RNA was reverse transcribed into cDNA using innuSCRIPT One Step RT_PCR SyGreen kit (ANALYTIK JENA). Primers listed in Table 2.

Briefly, RT-qPCR was performed using $1 \mu 1$ of cDNA and $0.2 \mu \mathrm{M}$ primers in $10 \mu \mathrm{l}$ of qPCR mixture. The PCR cycle conditions were as follows: preincubation for 10 seconds at $95^{\circ} \mathrm{C}$, annealing at $60^{\circ} \mathrm{C}$ for 30 seconds, and extension at $72^{\circ} \mathrm{C}$ for 1 minute followed by 40 cycles. Each sample was analyzed in triplicate and the mean of three experiments value used as the relative quantification.

The relative expression of all CDKs determined via $\boldsymbol{\Delta} \boldsymbol{\Delta} \mathrm{Ct}$ method, which normalized with reference https:// pubmed.ncbi.nlm.nih.gov/

(GAPDH). The threhold cycle $(\mathrm{Ct})$ was manually calculated for each CDK gene (gene of interest) and normalized to GAPDH. Relative expression levels of each target $\mathrm{CDK}$ gene expressed as $\boldsymbol{\Delta} \mathrm{Ct}$, which was calculated as $\boldsymbol{\Delta} \mathrm{Ct}=\mathrm{Ct}$ gene of interest $-\mathrm{Ct}$ Reference gene (GAPDH). However relative expression calculated as $\boldsymbol{\Delta} \mathrm{Ct}$ (gene of interest)- $\boldsymbol{\Delta} \mathrm{Ct}($ Reference gene $)=\boldsymbol{\Delta} \boldsymbol{\Delta} \mathrm{Ct}$.

\section{Statistical analysis}

For statistical analysis, the ANOVA test was used to analyze the significance of the differential expression pattern. The significance was defined as a p-value $<0.05$. Shapiro-Wilk test used to analyze the difference in the expression level between two groups (pre-menopausal and postmenopausal) and $\boldsymbol{\Delta} \mathrm{Ct}$ values were obtained for each stage and control group.

\section{ABBREVIATIONS}

CDK: cyclin-dependent kinases, BC: breast cancer, HER2+: Human epidermal growth factor receptor 2 positive, Ct: Cycle threshold, ER: Estrogen receptors, PR: progesterone receptor, GAPDH: Glyceraldehyde 3-phosphate dehydrogenase, TNM: Tumour, Node, Metastasis.

\section{Author contributions}

SM has designed, wrote the manuscript, and oversaw the conduct of this present study. MFHQ, MS, ML, ZJA, DM, RG, HF, IZ, RT, ST, and GH contributed to the questionnaire design and liaison with the studied hospitals, performed the experiments, reviewed the literature, analyzed the data and drafted the manuscript under the supervision of SM. All authors have approved the final version of this manuscript.

\section{CONFLICTS OF INTEREST}

The authors declare no competing interest.

\section{FUNDING}

Research work supported by Ziauddin University Multidisciplinary Laboratory (MDRL) and Pathological \& Molecular Laboratories, Clifton Karachi.

\section{REFERENCES}

1. Parkin DM, Bray F, Ferlay J, Pisani P. Estimating the world cancer burden: Globocan 2000. Int J Cancer. 2001; 94:15356. https://doi.org/10.1002/ijc.1440. PMID:11668491

2. Gnerlich JL, Deshpande AD, Jeffe DB, Sweet A, White $\mathrm{N}$, Margenthaler JA. Elevated breast cancer mortality in women younger than age 40 years compared with older women is attributed to poorer survival in early-stage disease. J Am Coll Surg. 2009; 208:341-47. https://doi. org/10.1016/j.jamcollsurg.2008.12.001. PMID:19317994

3. Bollet MA, Sigal-Zafrani B, Mazeau V, Savignoni A, de la Rochefordière A, Vincent-Salomon A, Salmon R, Campana F, Kirova YM, Dendale R, Fourquet A. Age remains the first prognostic factor for loco-regional breast cancer recurrence in young ( $<40$ years) women treated with breast conserving surgery first. Radiother Oncol. 2007; 82:272-80. https://doi. org/10.1016/j.radonc.2007.01.001. PMID:17287037

4. Aryandono T, Harijadi, Soeripto. Breast cancer in young women: prognostic factors and clinicopathological features. Asian Pac J Cancer Prev. 2006; 7:451-54. PMID:17059343

5. Luzzati T, Parenti A, Rughi T. Economic growth and cancer incidence. Ecol Econ. 2018; 146:381-96. https://doi. org/10.1016/j.ecolecon.2017.11.031.

6. World Health Organization. POPULATION FACT SHEETS. http://gco.iarc.fr/today/fact-sheets-populations

7. El Saghir NS, Khalil MK, Eid T, El Kinge AR, Charafeddine M, Geara F, Seoud M, Shamseddine AI. Trends in epidemiology and management of breast cancer in developing Arab countries: a literature and registry analysis. Int J Surg. 2007; 5:225-33. https://doi.org/10.1016/j. ijsu.2006.06.015. PMID:17660128

8. Bhurgri Y, Bhurgri A, Hassan SH, Zaidi SH, Rahim 
A, Sankaranarayanan R, Parkin DM. Cancer incidence in Karachi, Pakistan: first results from Karachi Cancer Registry. Int J Cancer. 2000; 85:325-29. https://doi. org/10.1002/(SICI)1097-0215(20000201)85:3<325::AIDIJC5>3.0.CO;2-J. PMID:10652421

9. Yasmeen F, Zaheer S. Functional time series models to estimate future age specific breast Cancer incidence rates for women in Karachi, Pakistan. J Health Sci. 2014; 2:21321.

10. Gómez-Caro A, Piñero A, Roca MJ, Torres J, Ferri B, Galindo PJ, Parrilla P. Surgical treatment of solitary metastasis in the male breast from non-small cell lung cancer. Breast J. 2006; 12:366-67. https://doi.org/10.1111/ j.1075-122X.2006.00278.x. PMID: 16848849

11. Ramar K, Pervez H, Potti A, Mehdi S. Breast metastasis from non-small-cell lung carcinoma. Med Oncol. 2003; 20:181-84. $\quad$ https://doi.org/10.1385/MO:20:2:181. PMID:12835522

12. Masmoudi A, Mathieu MC, Soria JC. Breast metastasis from lung adenocarcinoma: a case report. Anticancer Res. 2003; 23:1825-26. PMID:12820464

13. Reck M, Heigener DF, Mok T, Soria JC, Rabe KF, Management of non-small-cell lung cancer: recent developments. Lancet. 2013; 382:709-19. https://doi. org/10.1016/S0140-6736(13)61502-0. PMID:23972814

14. Ross JS, Slodkowska EA, Symmans WF, Pusztai L, Ravdin PM, Hortobagyi GN. The HER-2 receptor and breast cancer: ten years of targeted anti-HER-2 therapy and personalized medicine. Oncologist. 2009; 14:320 68. https://doi.org/10.1634/theoncologist.2008-0230. PMID:19346299

15. Veeraraghavan J, De Angelis C, Reis-Filho JS, Pascual T, Prat A, Rimawi MF, Osborne CK, Schiff R. De-escalation of treatment in HER2-positive breast cancer: determinants of response and mechanisms of resistance. Breast. 2017 (Suppl 1); 34:S19-26. https://doi.org/10.1016/j.breast.2017.06.022. PMID:28687441

16. Kwapisz D. Cyclin-dependent kinase $4 / 6$ inhibitors in breast cancer: palbociclib, ribociclib, and abemaciclib. Breast Cancer Res Treat. 2017; 166:41-54. https://doi.org/10.1007/ s10549-017-4385-3. PMID:28741274

17. Zhao X, Mirza S, Alshareeda A, Zhang Y, Gurumurthy CB, Bele A, Kim JH, Mohibi S, Goswami M, Lele SM, West W, Qiu F, Ellis IO, et al. Overexpression of a novel cell cycle regulator ecdysoneless in breast cancer: a marker of poor prognosis in HER2/neu-overexpressing breast cancer patients. Breast Cancer Res Treat. 2012; 134:171-80. https://doi.org/10.1007/s10549-011-1946-8. PMID:22270930

18. Casimiro MC, Crosariol M, Loro E, Li Z, Pestell RG. Cyclins and cell cycle control in cancer and disease. Genes Cancer. 2012; 3:649-57. https://doi. org/10.1177/1947601913479022. PMID:23634253
19. Parton M, Dowsett M, Smith I. Studies of apoptosis in breast cancer. BMJ. 2001; 322:1528-32. https://doi. org/10.1136/bmj.322.7301.1528. PMID:11420276

20. Voudouri K, Berdiaki A, Tzardi M, Tzanakakis GN, Nikitovic D. Insulin-like growth factor and epidermal growth factor signaling in breast cancer cell growth: focus on endocrine resistant disease. Anal Cell Pathol (Amst). 2015; 2015:975495. https://doi.org/10.1155/2015/975495. PMID:26258011

21. Iacopetta D, Rechoum Y, Fuqua SA. The Role of Androgen Receptor in Breast Cancer. Drug Discov Today Dis Mech. 2012; 9:e19-27. https://doi.org/10.1016/j. ddmec.2012.11.003. PMID:26568765

22. García-Reyes B, Kretz AL, Ruff JP, von Karstedt S, Hillenbrand A, Knippschild U, Henne-Bruns D, Lemke J. The Emerging Role of Cyclin-Dependent Kinases (CDKs) in Pancreatic Ductal Adenocarcinoma. Int J Mol Sci. 2018; 19:3219. https://doi.org/10.3390/ijms19103219. PMID:30340359

23. Otto T, Sicinski P. Cell cycle proteins as promising targets in cancer therapy. Nat Rev Cancer. 2017; 17:93-115. https://doi.org/10.1038/nrc.2016.138. PMID:28127048

24. Dhillon S. Palbociclib: first global approval. Drugs. 2015; 75:543-51. https://doi.org/10.1007/s40265-015-0379-9. PMID:25792301

25. Beaver JA, Amiri-Kordestani L, Charlab R, Chen W, Palmby T, Tilley A, Zirkelbach JF, Yu J, Liu Q, Zhao L, Crich J, Chen XH, Hughes M, et al. FDA approval: palbociclib for the treatment of postmenopausal patients with estrogen receptor-positive, HER2-negative metastatic breast cancer. Clin Cancer Res. 2015; 21:4760-66. https://doi.org/10.1158/1078-0432.CCR-15-1185. PMID:26324739

26. Peyressatre M, Prével C, Pellerano M, Morris MC. Targeting cyclin-dependent kinases in human cancers: from small molecules to Peptide inhibitors. Cancers (Basel). 2015; 7:179-237. https://doi.org/10.3390/cancers7010179. PMID:25625291

27. Jia B, Choy E, Cote G, Harmon D, Ye S, Kan Q, Mankin $\mathrm{H}$, Hornicek F, Duan Z. Cyclin-dependent kinase 11 (CDK11) is crucial in the growth of liposarcoma cells. Cancer Lett. 2014; 342:104-12. https://doi.org/10.1016/j. canlet.2013.08.040. PMID:24007862

28. Duan Z, Zhang J, Choy E, Harmon D, Liu X, Nielsen P, Mankin H, Gray NS, Hornicek FJ. Systematic kinome shRNA screening identifies CDK11 (PITSLRE) kinase expression is critical for osteosarcoma cell growth and proliferation. Clin Cancer Res. 2012; 18:4580-88. https://doi.org/10.1158/1078-0432.CCR-12-1157. PMID:22791884

29. Liu X, Gao Y, Shen J, Yang W, Choy E, Mankin H, Hornicek FJ, Duan Z. Cyclin-Dependent Kinase 11 (CDK11) Is Required for Ovarian Cancer Cell Growth 
In Vitro and In Vivo, and Its Inhibition Causes Apoptosis and Sensitizes Cells to Paclitaxel. Mol Cancer Ther. 2016; 15:1691-701. https://doi.org/10.1158/1535-7163.MCT-160032. PMID:27207777

30. Blazek D, Kohoutek J, Bartholomeeusen K, Johansen E, Hulinkova P, Luo Z, Cimermancic P, Ule J, Peterlin BM. The Cyclin K/Cdk12 complex maintains genomic stability via regulation of expression of DNA damage response genes. Genes Dev. 2011; 25:2158-72. https://doi. org/10.1101/gad.16962311. PMID:22012619

31. Cheng SW, Kuzyk MA, Moradian A, Ichu TA, Chang VC, Tien JF, Vollett SE, Griffith M, Marra MA, Morin GB. Interaction of cyclin-dependent kinase $12 / \mathrm{CrkRS}$ with cyclin $\mathrm{K} 1$ is required for the phosphorylation of the C-terminal domain of RNA polymerase II. Mol Cell Biol. 2012; 32:4691-704. https://doi.org/10.1128/MCB.0626711. PMID:22988298

32. Ekumi KM, Paculova H, Lenasi T, Pospichalova V, Bösken CA, Rybarikova J, Bryja V, Geyer M, Blazek D, Barboric M. Ovarian carcinoma CDK12 mutations misregulate expression of DNA repair genes via deficient formation and function of the $\mathrm{Cdk} 12 / \mathrm{CycK}$ complex. Nucleic Acids Res. 2015; 43:2575-89. https://doi.org/10.1093/nar/gkv101. PMID:25712099

33. Becker F, Joerg V, Hupe MC, Roth D, Krupar R, Lubczyk V, Kuefer R, Sailer V, Duensing S, Kirfel J, Merseburger AS, Brägelmann J, Perner S, Offermann A. Increased mediator complex subunit CDK19 expression associates with aggressive prostate cancer. Int J Cancer. 2020; 146:577-88. https://doi.org/10.1002/ijc.32551. PMID:31271443

34. Audetat KA, Galbraith MD, Odell AT, Lee T, Pandey A, Espinosa JM, Dowell RD, Taatjes DJ. A KinaseIndependent Role for Cyclin-Dependent Kinase 19 in p53 Response. Mol Cell Biol. 2017; 37:e00626-16. https://doi. org/10.1128/MCB.00626-16. PMID:28416637

35. Tian Y, Wan H, Tan G. Cell cycle-related kinase in carcinogenesis. Oncol Lett. 2012; 4:601-06. https://doi. org/10.3892/ol.2012.828. PMID:23205069

36. An X, Ng SS, Xie D, Zeng YX, Sze J, Wang J, Chen YC, Chow BK, Lu G, Poon WS, Kung HF, Wong BC, Lin MC. Functional characterisation of cell cycle-related kinase (CCRK) in colorectal cancer carcinogenesis. Eur J Cancer. 2010; 46:1752-61. https://doi.org/10.1016/j. ejca.2010.04.007. PMID:20466538

37. Barone G, Staples CJ, Ganesh A, Patterson KW, Bryne DP, Myers KN, Patil AA, Eyers CE, Maslen S, Skehel JM, Eyers PA, Collis SJ. Human CDK18 promotes replication stress signaling and genome stability. Nucleic Acids Res. 2016; 44:8772-85. https://doi.org/10.1093/nar/gkw615. PMID:27382066

38. Swain SM, Baselga J, Kim SB, Ro J, Semiglazov V, Campone M, Ciruelos E, Ferrero JM, Schneeweiss A, Heeson S, Clark E, Ross G, Benyunes MC, Cortés J, and
CLEOPATRA Study Group. Pertuzumab, trastuzumab, and docetaxel in HER2-positive metastatic breast cancer. N Engl J Med. 2015; 372:724-34. https://doi.org/10.1056/ NEJMoa1413513. PMID:25693012

39. Chung A, Cui X, Audeh W, Giuliano A. Current status of anti-human epidermal growth factor receptor 2 therapies: predicting and overcoming herceptin resistance. Clin Breast Cancer. 2013; 13:223-32. https://doi.org/10.1016/j. clbc.2013.04.001. PMID:23829888

40. Barone G, Arora A, Ganesh A, Abdel-Fatah T, Moseley P, Ali R, Chan SY, Savva C, Schiavone K, Carmell N, Myers KN, Rakha EA, Madhusudan S, Collis SJ. The relationship of CDK18 expression in breast cancer to clinicopathological parameters and therapeutic response. Oncotarget. 2018; 9:29508-24. https://doi.org/10.18632/oncotarget.25686. PMID:30034634

41. Leonardi M, Perna E, Tronnolone S, Colecchia D, Chiariello M. Activated kinase screening identifies the IKBKE oncogene as a positive regulator of autophagy. Autophagy. 2019; 15:312-26. https://doi.org/10.1080/155 48627.2018.1517855. PMID:30289335

42. Chaput D, Kirouac L, Stevens SM Jr, Padmanabhan J. Potential role of PCTAIRE-2, PCTAIRE-3 and P-Histone $\mathrm{H} 4$ in amyloid precursor protein-dependent Alzheimer pathology. Oncotarget. 2016; 7:8481-97. https://doi. org/10.18632/oncotarget.7380. PMID:26885753

43. Daniels DL, Ford M, Schwinn MK, Benink H, Galbraith MD, Amunugama R, Jones R, Allen D, Okazaki N, Yamakawa H, Miki F, Nagase T, Espinosa JM and Urh M. Mutual exclusivity of MED12/MED12L, MED13/13L, and CDK8/19 paralogs revealed within the CDK-mediator kinase module. J Proteomics Bioinform. 2013; S2:1-7 https://doi.org/10.4172/jpb.S2-004

44. Galbraith MD, Allen MA, Bensard CL, Wang X, Schwinn MK, Qin B, Long HW, Daniels DL, Hahn WC, Dowell RD, Espinosa JM. HIF1A employs CDK8-mediator to stimulate RNAPII elongation in response to hypoxia. Cell. 2013; 153:1327-39. https://doi.org/10.1016/j.cell.2013.04.048. PMID:23746844

45. Brägelmann $\mathrm{J}$, Klümper $\mathrm{N}$, Offermann $\mathrm{A}$, von Mässenhausen A, Böhm D, Deng M, Queisser A, Sanders C, Syring I, Merseburger AS, Vogel W, Sievers E, Vlasic I, et al. Pan-cancer analysis of the mediator complex transcriptome identifies CDK19 and CDK8 as therapeutic targets in advanced prostate cancer. Clin Cancer Res. 2017; 23:1829-40. https://doi.org/10.1158/1078-0432.CCR-160094. PMID:27678455

46. Liu Y, Wu C, Galaktionov K. p42, a novel cyclin-dependent kinase-activating kinase in mammalian cells. J Biol Chem. 2004; 279:4507-14. https://doi.org/10.1074/jbc. M309995200. PMID:14597612

47. Wang Q, Ma J, Lu Y, Zhang S, Huang J, Chen J, Bei JX, Yang K, Wu G, Huang K, Chen J, Xu S. CDK20 
interacts with KEAP1 to activate NRF2 and promotes radiochemoresistance in lung cancer cells. Oncogene. 2017; 36:5321-30. https://doi.org/10.1038/onc.2017.161. PMID:28534518

48. Yu Z, Gao YQ, Feng H, Lee YY, Li MS, Tian Y, Go MY, Yu DY, Cheung YS, Lai PB, Yu J, Wong VW, Sung JJ, et al. Cell cycle-related kinase mediates viral-host signalling to promote hepatitis B virus-associated hepatocarcinogenesis. Gut. 2014; 63:1793-804. https://doi.org/10.1136/ gutjnl-2013-305584. PMID:24440987

49. Feng H, Yu Z, Tian Y, Lee YY, Li MS, Go MY, Cheung YS, Lai PB, Chan AM, To KF, Chan HL, Sung JJ, Cheng AS. A CCRK-EZH2 epigenetic circuitry drives hepatocarcinogenesis and associates with tumor recurrence and poor survival of patients. J Hepatol. 2015; 62:1100-11. https://doi.org/10.1016/j.jhep.2014.11.040. PMID:25500144

50. Wu GQ, Xie D, Yang GF, Liao YJ, Mai SJ, Deng HX, Sze J, Guan XY, Zeng YX, Lin MC, Kung HF. Cell cycle-related kinase supports ovarian carcinoma cell proliferation via regulation of cyclin D1 and is a predictor of outcome in patients with ovarian carcinoma. Int J Cancer. 2009; 125:2631-42. https://doi.org/10.1002/ijc.24630. PMID: 19672860

51. Sun B, Mason S, Wilson RC, Hazard SE, Wang Y, Fang R, Wang Q, Yeh ES, Yang M, Roberts TM, Zhao JJ, Wang Q. Inhibition of the transcriptional kinase CDK7 overcomes therapeutic resistance in HER2-positive breast cancers. Oncogene. 2020; 39:50-63. https://doi.org/10.1038/s41388019-0953-9. PMID:31462705

52. Drogat J, Migeot V, Mommaerts E, Mullier C, Dieu M, van Bakel H, Hermand D. Cdk11-cyclinL controls the assembly of the RNA polymerase II mediator complex. Cell Rep. 2012; 2:1068-76. https://doi.org/10.1016/j. celrep.2012.09.027. PMID:23122962

53. Hu D, Mayeda A, Trembley JH, Lahti JM, Kidd VJ. CDK11 complexes promote pre-mRNA splicing. J Biol Chem. 2003; 278:8623-29. https://doi.org/10.1074/jbc. M210057200. PMID:12501247

54. Zhou Y, Han C, Li D, Yu Z, Li F, Li F, An Q, Bai H, Zhang X, Duan Z, Kan Q. Cyclin-dependent kinase 11(p110) (CDK11(p110)) is crucial for human breast cancer cell proliferation and growth. Sci Rep. 2015; 5:10433. https:// doi.org/10.1038/srep10433. PMID:25990212

55. Wilkinson S, Croft DR, O'Prey J, Meedendorp A, O'Prey M, Dufès C, Ryan KM. The cyclin-dependent kinase PITSLRE/CDK11 is required for successful autophagy. Autophagy. 2011; 7:1295-301. https://doi.org/10.4161/ auto.7.11.16646. PMID:21808150

56. Ko TK, Kelly E, Pines J. CrkRS: a novel conserved Cdc2related protein kinase that colocalises with SC35 speckles. J Cell Sci. 2001; 114:2591-603. PMID:11683387
57. Fagerberg L, Hallström BM, Oksvold P, Kampf C, Djureinovic D, Odeberg J, Habuka M, Tahmasebpoor S, Danielsson A, Edlund K, Asplund A, Sjöstedt E, Lundberg $\mathrm{E}$, et al. Analysis of the human tissue-specific expression by genome-wide integration of transcriptomics and antibodybased proteomics. Mol Cell Proteomics. 2014; 13:397-406. https://doi.org/10.1074/mcp.M113.035600.

58. Joshi PM, Sutor SL, Huntoon CJ, Karnitz LM. Ovarian cancer-associated mutations disable catalytic activity of CDK12, a kinase that promotes homologous recombination repair and resistance to cisplatin and poly(ADP-ribose) polymerase inhibitors. J Biol Chem. 2014; 289:9247-53. https://doi.org/10.1074/jbc.M114.551143. PMID:24554720

59. Iniguez AB, Stolte B, Wang EJ, Conway AS, Alexe G, Dharia NV, Kwiatkowski N, Zhang T, Abraham BJ, Mora J, Kalev P, Leggett A, Chowdhury D, et al. EWS/FLI Confers Tumor Cell Synthetic Lethality to CDK12 Inhibition in Ewing Sarcoma. Cancer Cell. 2018; 33:202-216.e6. https:// doi.org/10.1016/j.ccell.2017.12.009. PMID:29358035

60. Toyoshima M, Howie HL, Imakura M, Walsh RM, Annis JE, Chang AN, Frazier J, Chau BN, Loboda A, Linsley PS, Cleary MA, Park JR, Grandori C. Functional genomics identifies therapeutic targets for MYC-driven cancer. Proc Natl Acad Sci USA. 2012; 109:9545-50. https://doi. org/10.1073/pnas.1121119109. PMID:22623531 